Журнал «Герспективитаінноваціїнауки»

(Серія«Гедагогіка»), Серія«ГТихологія», Серія «Медицина»

№5(5) 2021

УДК - 78.01

https://doi.org/10.52058/2786-4952 -2021-5(5)-218-227

Грінченко Тетяна Дмитрівна кандидат педагогічних наук, доцент кафедри музикознавства, інструментальної підготовки та хореографії, Вінницький державний педагогічний університет імені Михайла Коцюбинського, вул. Острозького 32, м. Вінниця, 21000, тел.: (043) 227-93-92, e-mail: tatyana_grinchenko@ukr.net, https://orcid.org/0000-0001-8084-6732

\title{
НОВА ГЕНЕРАЦІЯ УКРАЇНСЬКИХ МУЗИКАНТІВ: ПЕДАГОГІЧНІ ПРИНЦИПИ РОМАНА ЛОПАТИНСЬКОГО
}

Анотація. У статті розглядаються педагогічні принципи музиканта нової генерації України, Романа Лопатинського, ім'я якого як піаніста-виконавця широко відоме далеко за межами нашої країни. Він $є$ переможцем престижних конкурсів, географія його виступів $є$ надзвичайно об'ємною: 3 сольними концертами та в якості соліста 3 оркестром він виступав у престижних залах Японії, Сполучених штатів Америки, Франції, Австралії, Італії, Австрії та інших країнах світу. Як випускник Київської середньої спеціальної школи імені М.Лисенка, національної музичної академії імені П.Чайковського, Р.Лопатинський є носієм знань, традицій і музичного досвіду української національної фортепіанної школи, окрім того, велика кількість міжнародних конкурсів, фестивалів, майстеркласів, в яких він брав участь, навчання у закордонних закладах музичної освіти, викликають науковий інтерес до особистості Романа Лопатинського як педагога, до принципів, якими він керується у своїй викладацькій діяльності.

Нашу увагу привернули майстеркласи, які містяться в мережі інтернет і $\epsilon$ доступними для широкого кола слухачів. Основна частина статті присвячена науковому обгрунтуванню педагогічних вказівок, викладенню принципових позицій щодо фортепіанного виконавства, продемонстрованих Р.Лопатинським у роботі зі студентами над наступними творами: Ф.Ліст Соната сі мінор, Ф.Шопен скерцо №3, Ф.Ліст Рапсодія №2, В.Моцарт Соната ля мінор №8 К.310. Відповідно до даних творів була окреслена тематика майстеркласів: «Робота над особливостями стилю в творах композиторів-романтиків» та «Розвиток творчих здібностей виконавців у процесі вивчення творів композиторів-класиків».

Сформована система педагогічних цінностей $\mathrm{i}$ принципів Р.Лопатинського, базується на педантизмі у ставленні до авторських текстів, зверненні особливої уваги на чіткість виконання ритмічних фігур, обов'язковому прояві індивідуальності виконавця, технологічному тяжінні до мінімалізму рухів, визнанні слухового контролю однією із головних якостей музиканта-виконавця. 
Ключові слова: Роман Лопатинський, музична педагогіка, українська піаністична школа, система музично-педагогічних принципів, слуховий контроль, розуміння авторського тексту.

Hrinchenko Tetiana Dmitrievna Candidate of Pedagogical Sciences, Associate Professorin the Department of Musicology, Instrumental Training and Choreography of Vinnitsa State Pedagogical University named after Mikhail Kotsyubinsky, Ostroh St., 32, Vinnytsia, 21000, tel.: (043) 227-93-92, e-mail: tatyana_grinchenko@ukr.net, https://orcid.org/0000-0001-8084-6732

\section{NEW GENERATION OF UKRAINIAN MUSICIANS: PEDAGOGICAL PRINCIPLES OF LOPATINSKY'S ROMAN}

Abstract. The article examines the pedagogical principles of the new generation of Ukraine musician, Roman Lopatinsky, whose name as a pianistperformer is widely known far beyond the borders of our country. He is the winner of prestigious competitions, the geography of his performances is extremely extensive: with solo concerts and as a soloist with an orchestra, he performed in prestigious halls in Japan, the United States of America, France, Australia, Italy, Austria and other countries of the world. As a graduate of the Kiev secondary special school named after M. Lysenko, the National Music Academy named after P. Tchaikovsky, R. Lopatinsky is a carrier of knowledge, traditions and musical experience of the Ukrainian National Piano School, in addition, a large number of international competitions, festivals, masterclasses in which he participated, training in foreign institutions of music education, cause scientific interest in the personality of Roman Lopatinsky as a teacher, to the principles that guide him in his teaching activities.

Our attention was drawn to the master classes that are available on the internet and are available to a wide range of listeners. The main part of the article is devoted to the scientific substantiation of pedagogical instructions, the presentation of fundamental positions on piano performance, demonstrated by R. Lopatinsky in his work with students on the following works: F. Liszt Sonata in B minor, F. Chopin Scherzo No. 3, F. Liszt Rhapsody No. 2, V. Mozart sonata in a minor No. 8 K. 310. In accordance with these works, the topics of the master classes were outlined: "work on the peculiarities of style in the works of Romantic composers" and "development of creative abilities of performers in the process of studying the works of classical composers".

The system of pedagogical values and principles of R. Lopatinsky is formed, it is based on pedantry in relation to the author's texts, paying special attention to the clarity of the performance of rhythmic figures, the obligatory manifestation of the performer's personality, the technological attraction to minimalism of movements, the recognition of auditory control as one of the main qualities of a musicianperformer. 
Журнал«Герспективитаінновації наукиљ

(Серія«Гедагогіка», Серія«ГЕихологія», Серія «Медицин»

№5(5) 2021

Keywords: Roman Lopatinsky, music pedagogy, Ukrainian piano school, system of musical and pedagogical principles, auditory control, understanding of the author's text.

Постановка проблеми. Ім'я українського піаніста Романа Лопатинського уже давно широко відоме далеко за межами нашої країни. Він активно пропагує класичну музику, виступає на різноманітних концертних майданчиках України та світу 3 сольними програмами, в якості соліста симфонічного оркестру, артиста камерного ансамблю, концертмейстера. Як випускник Київської середньої спеціальної школи імені М.Лисенка, національної музичної академії імені П.Чайковського, Р.Лопатинський є носієм знань, традицій і музичного досвіду української національної фортепіанної школи, окрім того, велика кількість міжнародних конкурсів, фестивалів, майстеркласів, в яких він брав участь, навчання у закордонних закладах музичної освіти, викликають науковий інтерес до особистості Романа Лопатинського як педагога, до принципів, якими він керується у своїй викладацькій діяльності.

Аналіз останніх досліджень і публікацій. В репертуарі Р.Лопатинського твори усіх музичних напрямків та стилів. В його виконанні однаково переконливо звучить Й.С.Бах і П.Хіндеміт, С.Рахманінов і С.Прокоф'єв. Однак музикознавчих, музично-педагогічних та наукових досліджень творчості P.І.Лопатинського нині поки що не існує, а тому джерелами нашого дослідження $€$ численні інтерв'ю піаніста вітчизняним i закордонним мистецьким засобам масової інформації, його особисті промови перед концертами тощо. Особливої уваги, на нашу думку, заслуговують майстеркласи, які Роман Ілліч проводить зі студентами фахових мистецьких коледжів та музичних академій.

Метою даної статті $\epsilon$ знайомство з біографією та творчістю Романа Ілліча Лопатинського як одного із найяскравіших представників нової генерації українських класичних музикантів в галузі виконавства та педагогіки та спроба науково обгрунтувати систему його музично-педагогічних принципів.

Виклад основного матеріалу. Р.Лопатинський народився в 1993 році в сім'ї музикантів піаністів. Навчання на фортепіано розпочав з п'яти років у Київській середній спеціальній школі імені Миколи Лисенка в класі відомого педагога Ірини Баринової. Коло захоплень музикою в роки навчання у спеціалізованій школі не обмежувалось лише фортепіано: як згадує сам піаніст, у шостому класі деякий час він навчався грі на скрипці, впродовж чотирьох років грав на ударних інструментах у симфонічному оркестрі школи, захоплювався симфонічним диригуванням. Усі ці захоплення допомагали йому у розвитку визначеної генеральної лінії - піаністичної.

Національну музичну академію імені П.І.Чайковського закінчив по класу доцента Сергія Рябова. Свою фортепіанну освіту збагачував на численних майстеркласах, у спілкуванні з видатними музикантами сучасності. У віці 
шістнадцяти років, завдяки своїй обдарованості, був зарахований до Академії Internazionale di Imola «Incontri con il Maestro» Італія в клас професора Бориса Петрушанського. 3 дитинства був стипендіатом таких фондів як «Приятелі дітей» (2005-2008), Благодійний фонд Швейцарії (2008), Благодійний фонд Влади Прокаєвої «Обдаровані діти - майбутнє України» (2009, 2010), Президентського фонду Л.Кучми «Україна». 32017 року отримує грантову підтримку від фонду VERE MUSIC FUND та бере участь у спеціальних проектах фонду.

Географія виступів Р.Лопатинського є досить об’ємною: 3 сольними концертами та в якості соліста з оркестром він виступав у престижних залах Японії, Сполучених штатів Америки, Франції, Австралії, Італії, Австрії та багатьох інших країн світу. Брав участь у знакових міжнародних фестивалях «MITO» (Турін, Мілан), «Newport Festival» (Нью-Порт, США), концерт - лекція в Sorbonne Université (Париж), «Лики современного пианизма» (СанктПетербург), «The next Generation Festival» (Бад-Рагац, Швейцарія), «Тhe Festival Heidelberger Frühling» (Німеччина), «Animato» (Париж), «Гогольфест» (Київ), «LvivMozArt» (Львів), «Bouquet Kyiv Stage» (Київ), виступав з такими відомими диригентами, як Міхаель Зандерлінг, Франческо Омаззіні, Марко Боні, Такасекі Кен, Тао Фан, Теодор Кучар, Ніколя Краузе, Володимир Сіренко. «Я активно просуваю у своєму житті дві лініі: як соліст-піаніст, який грає сольні програми, виступає з оркестром, їздть на конкурси, збирає великі зали на фестивалях. I друга лінія - це камерний ансамбль, який ми створили 3 моїми колегами, - Nota Bene chamber group» - так про себе говорить Р.Лопатинський в інтерв'ю вітчизняним засобам масової інформації [1]. Сьогодні Р.Лопатинський також є учасником відомого українського колективу Лятошинський Тріо. Свою педагогічну діяльність доповнює проведенням майстеркласів з молодими талановитими піаністами України та світу. Одним із завдань нашої статті $€$ здійснення характеристики принципів та методів музичної педагогіки, які Р.Лопатинський застосовує у своїй педагогічній діяльності, що дозволить дослідити успадковані ним провідні засади української піаністичної школи та методи навчання викладачів світового рівня, 3 якими йому довелося співпрацювати.

В рамках творчої зустрічі у філармонії м.Суми відбулись майстер-класи Р.Лопатинського для студентів та викладачів відділу спеціального та загального фортепіано коледжу, викладачів мистецьких навчальних закладів області на теми: «Робота над особливостями стилю в творах композиторівромантиків» та «Розвиток творчих здібностей виконавців у процесі вивчення творів композиторів-класиків»[2]. Слід відмітити достатньо високий виконавський рівень студентів, 3 якими проводився майстерклас: у першому розділі, в якому звучала музика доби романтизму, робота велась над Сонатою сі мінор Ф.Ліста, Скерцо №3 Ф.Шопена, Другою рапсодією Ф.Ліста.

Вже $з$ перших тактів Сонати Ф.Ліста Р.Лопатинський звернув увагу учня на необхідність педантичного дотримання авторського тексту i чіткого 
виконання ритмічних фігур (наприклад, виконання пунктирного ритму має відбуватися без тяжіння до скорочення короткої ноти), довгі ноти пропонувалося заповнювати дрібною пульсацією. На його думку, вступ характеризується невблаганністю і тому має виконуватися без найменших темпових коливань. Виконання має бути не одним із «багатьох», воно має бути індивідуальним, неповторним, цьому має сприяти попереднє утворення в уяві виконавця «таблиці» пульсації необхідних тривалостей, яка дозволить відчувати пульс твору впродовж всього його звучання. Тенденція до дотримання правил виконання музичного ритму $\epsilon$ однією iз головних, наскрізних ідей, до якої викладач Р.Лопатинський звертався впродовж проведення майстеркласу. Цікавим виявився факт, що при всій об’ємності репертуару, яким володіє піаніст, 3 його слів, Соната Ф.Ліста сі мінор «По прочитанню Данте» не входить до його репертуарного списку. Слід відзначити високий рівень вміння піаніста читати з листа, а також його миттєву реакцію на найдрібніші текстові неточності у виконанні учня. Це доводить, що в українській національній фортепіанній школі існують i продовжують втілюватись у виконавстві ідеї філігранності у прочитанні авторських текстів.

Вимоги до строгого дотримання авторських вказівок впродовж роботи над Сонатою сі мінор Ф.Ліста поширювалися на використання засобів музичної виразності, а саме побудову видимої динамічної шкали: в роботі над Allegro enerdgico Р.Лопатинський пропонував учневі не «виплескувати», «берегти звук» i на початку твору не захоплюватись силою звучання, думати про необхідність виплеску потрібної сили у більш напружених смислових кульмінаціях. Називаючи ліричну побічну партію «чарівною» викладач просив учня вже в експозиції передбачати майбутні «тихі» кульмінації, приберегти пронизливість piano для вирішальних частин форми.

Впродовж майстеркласу велика увага приділялася виконанню смислових кульмінацій, наприклад першу появу $\mathrm{Mi}$ бемоль мажору Р.Лопатинський охарактеризував як «першу вагому подію» в сонаті. I тут важливо відмітити якість викладацького показу, в якому відчутне високоякісне підкорення використання піаністичних прийомів головній меті - розкриттю художнього образу твору. В цілому, спостереження за руками музиканта дає можливість констатувати його тяжіння до мінімалізму рухів, застосування їх рівно у такій кількості, скільки потрібно для виконання тієї чи іншої музичної фігурації. Особливо це ставало помітним у порівнянні з рухами учня, якому поки що одного об'єднуючого руху руки не вистачає для виконання одного мотиву, однієї музичної думки. «Скромна поведінка рук» - саме так викладач говорив про мінімалізацію рухів, ергономічність, раціоналізм, що ми спостерігаємо у його показах.

Під час заняття учень спонукався до розмежування, розділення фактури, в цілому, постійного залучення слухового контролю за усім, що відбувається в музичній тканині, до обов'язкового слідкування за лінією басу, до уявного усвідомлення діалогічності музичної думки, показу, наприклад, двох начал, 
одне $з$ яких тяжіє до нижнього регістру (пекло), а інше, навпаки, благає про можливість «виходу 3 клітки». Така поривчастість автором позначається вказівками короткого crescendo. Р.Лопатинський не радить виконувати accelerando там, де воно не вказане в нотах, бути уважним до закличних інтонацій, обов'язково звертати увагу і дослуховувати кожну акцентовану ноту. В октавних проведеннях sempre staccato ed enerdgiko assai викладач не побачив авторської вказівки на зміну темпу і попросив учня не прискорювати, пояснив, що для початку завжди потрібно грати «як написано, жорстко, безкомпромісно», даний епізод, 3 його слів, має бути «накопиченням залізобетонної волі».

Монологічні теми в Сонаті порівнювались 3 «внутрішнім голосом» героя, мова, на думку Р.Лопатинського, йде про «інший, потойбічний світ». I тут варто знову зупинитися на якості викладацького показу: в ньому демонструється безліч тембральних фарб, осмислюються і переосмислюються авторські задуми (Данте-Ліст), іноді потойбічність відчувається, бачиться, стає нереально реальною. Технічно така «нереальність» досягається завдяки використанню лівої педалі, сурдинізації звучання.

Щодо педалізації: 3 даного майстеркласу стає зрозумілим, що Р.Лопатинський $є$ прихильником чіткої звукової вимови, без педального «замазування». Гострі музичні відрізки (стаккато Ліста) рекомендує виконувати без педалі, лише зрідка «підфарбовувати» визначені відтяжки та зупинки. Слуховий контроль є головним у застосуванні педалей: використання лівої, різних градацій правої (чвертьпедаль, напівпедаль) на кожному роялі закономірно має бути різним і контролюватися вухом музиканта. В цілому, музикант Р.Лопатинським є прихильником використання лівої педалі, саме вона, на його думку, допомагає у побудові максимально різноманітної динамічної шкали.

3 даного майстеркласу стає зрозумілим, що Р.Лопатинский не $є$ прихильником частого застосування «переддихання», відтягування моменту наступу сильної долі - таке агогічне відхилення, на його думку, має бути одним iз дієвих, доречних, продуманих засобів музичної виразності. В цілому, пропонуючи музиці рухатися ніби у захопливому «польоті», викладач наполягав на простоті виконання, тяжінні до відсутності «музичних» відхилень, які іноді є ознакою відсутності музичного смаку.

В роботі над третім Скерцо Ф.Шопена Р.Лопатинський знову продемонстрував свою неприхильність i непримиримість 3 усілякого роду вільностями і неточностями. Гру без акцентів влучно назвав «грою на видиху». Вимагав виконання цезур «на благо» музики, навчав любити напівтони, порівнював їх 3 «раною, що кровоточить». Наполягав на постійному відчутті поліфонічності музичної тканини, прослуховуванні «серединки», у втіленні інтервальної семантики пропонував прослуховувати кожен інтервал; доводив, що «кульмінація - це можливість висловитися», вкотре наполягав, що не можна виконувати accelerando там, де його немає в нотах; вимагав 
структурованості пасажів, «оксамитового» тембру лівої руки, опорності на гармонію в цілому; пропонував зіграти фразу так, ніби «отримуєш благословіння на щось». Цілком виправданим, на нашу думку, є виконання sotto voce 3 використанням лівої педалі - в цьому $є$ прояв очікування, «не розкриття таємниць» - говорить Р.Лопатинський. Розрахунок на збільшення звуку є розрахунком на «подієвість», у даному скерцо зверненням до «інших, фантазійних світів».

Заняття у рамках теми «Робота над особливостями стилю в творах композиторів-романтиків» завершувалось роботою над Рапсодією №2 Ф.Ліста. Від студента знову вимагалась максимальна точність у виконанні ритмічних фігур, пауз, на значенні останніх увага акцентувалась особливо. Початок має бути фанфарним, ніби «в очікуванні чогось». Структуру твору викладач назвав «хребтом», відчуття якого має бути постійним і обов'язковим, так, як і відчуття угорського колориту, народності музики має бути присутнім постійно. Віртуозність виконання, на думку Р.Лопатинського, має досягатися швидкістю виконання пасажів, контрастність частин потрібно підкреслювати за допомогою фермат.

У вирішенні технічних проблем Р.Лопатинський дає, на нашу думку, досить слушні поради, наприклад, для зручності рекомендує не обов'язково грати «так як написано», можна користатися підміною рук. В каденціях заради досягнення якості виконання краще грати більш стримано, спокійно, ніж швидко, але не якісно.

В роботі над рапсодією викладач велику частку уроку приділив художності виконання, розкриттю художнього образу твору. Спочатку своє невдоволення він виявив щодо гри студента, порівняв іiі з засіданням у «сільгоспі, 3 паперовою волокитою, перерахуванням поголів'я» тощо. Причиною цього назвав неуважність учня до авторських позначок, вказівок. Пропонувалось звертати особливу увагу на раптовість пауз, тембральну окрасу різних мотивів у підголосках. Жодної зміни характеру, жодного $s f$ виконавець не має пропускати, постійно знаходитись у стані пошуку. Не дивлячись на те, що, зі слів Романа Ілліча, краще Володимира Горовиця ніхто не зможе краще зіграти цю Рапсодію, виконавцям обов'язково потрібно шукати у нотному тексті щось своє, реагувати на всі інтонаційні зміни, захоплюватися, дивуватися, радіти, сумувати тощо. Учневі пропонувалось долати салонність даного твору в пошуках глибинності народної мудрості, яка $є$ присутньою у кожній ноті, в терпкості гармонії, мелізмах, паузах тощо.

Цікавим виявився підхід до вирішення аплікатурних проблем у виконанні репетицій: на думку викладача, чергування 4,3,2 пальців не завжди $є$ ефективним, швидкість іноді ефективніше досягається чергуванням 3-2 пальців.

Генеральною лінією своїх майстеркласів Р.Лопатинський вважає «прибиранням усіляких завитків, бантиків». Від учнів він просить «зістригати їх», оскільки постійне заокруглення фраз негативно впливає на розвиток 
музичної думки, отже, не потрібно наприкінці кожних восьми тактів робити заокруглення, а у швидкісних частинах потрібно «влітати» в наступну фразу.

Найбільшою складністю у виконанні сі мінорної сонати і другої рапсодії Ф.Ліста Р.Лопатинський вважає необхідність чимось здивувати слухача. Вирішення цього завдання, на його думку, лежить в площині надуважного прочитання авторського тексту, до нього потрібно ставитися так, ніби ти сам пишеш цей твір, скурпульозно, ретельно вдивлятися у нотний текст i максимально застосовувати засоби музичної виразності.

В частині майстеркласу на тему «Розвиток творчих здібностей виконавців У процесі вивчення творів композиторів-класиків» робота велась над Сонатою В.А.Моцарта №8 К.310. Ця соната написана у досить незвичній для Моцарта тональності ля мінор. Й.Гайдн також намагався уникати їі, оскільки вважав тональністю смерті. Твір був написаний влітку 1778 року у Парижі, під час поїздки до Франції, що стала для Моцарта трагічною - саме в цей час померла мати композитора. Окрім того, не виправдались надії пошуку постійної роботи - французи замовляли, виконували музику композитора, але замовлення не оплачувались. Звідси звернення до незвичної мінорної тональності.

Прагнення до зразкової точності в усьому особливо проявились в роботі над твором музики віденського класика. Зверталась увага на правильність виконання форшлагів, завершення фраз, які мають нагадувати «поклони», важливість партії лівої руки, в якій відбуваються зміни гармонії, виконання кінцівок фраз «на видиху», чіткість і точність пунктирного ритму, а також зміни характеру музики, мажоро-мінорність, на яку виконавець має обов'язково звертати увагу. Учневі пропонувалось послухати гармонічну лінію без мелодичного заповнення, відчути ії плинність та зміни. Головним, на думку викладача, є різноманітність виконання мелодичних побудов, не важливо, яку динаміку обере виконавець, важливо, щоб музика була різною, іноді «затемненою», іноді «просвітленою», з показом домінанти та зміни мелодичногармонічних зворотів.

Під час виконання заключної партії у студентки виникла проблема 3 виконанням трелі, що призвело втрати темпу. 3 боку викладача одразу ж прозвучали наступні поради: при грі трелі більше потрібно думати про «вихід» 3 неї, всі дрібні ноти мають бути «рештою», виконуватися дуже легко, спрямовуватись до основної ноти; в той час ліва рука також має виконуватись полегшено, з направленістю до головної сильної долі. Все це було показано Р.Лопатинським на високому рівні i в його виконанні здавалося легким епізодом, в якому немає ніякої технічної складності. Слід зазначити, що поради і показ викладача відіграли свою роль і студентка справилася 3 завданням, зіграла епізод технічно правильно. Щодо арпеджато в кінці експозиції: його необхідно виконувати швидше, не розтягувати, а у виконанні довгих нот варто наслідувати струнні інструменти - «дотримувати ноту до кінця смичка».

Однією із головних вимог до виконання сонати Моцарта була вимога дотримання єдності темпу i, якщо на заваді цьому стають технічно складні 
місця, їх обов'язково потрібно допрацювати, перевести із розряду «важких» у розряд «легких», пам'ятати про свої «тяжіння до заповільнень» і з відчуттям обов'язкової внутрішньої пульсації постійно намагатися тримати себе у потрібному тонусі.

В розробці учениці пропонувалося відчувати накопичення енергії, яке Моцарт завершує арпеджованими пасажами. 3 точним прицілом можна виконувати на форте лише одну ноту, що є правильним, оскільки crescendo автором не прописується. Партію лівої руки пропонувалось грати 3 легким акцентуванням лише опорних нот, всі інші мають виконуватися надлегко, дуже легко, щоб не гальмувати процес музичного руху правої руки і в цілому не сповільнювати темп. Переклички рук влучно були названі «світлом і тінню».

Використання педалі в сонаті В.А.Моцарта, на думку Р.Лопатинського, має бути мінімальним, лише для легкого підкреслення окраси звуку, його тембральної фарби. В цілому, в музиці доби класицизму все має бути продуманим «пальцями» і сприяти ієрархії долей в такті. Зверталась увага на своєрідну «хитромудрість» лівої руки, яку музиканти доби бароко і класицизму обов'язково виконували б з підкресленим фразуванням.

В репризі музика має ставати ще більш стрімкою, але з чітким виконанням кадансів, що несуть на собі смислове навантаження висновку.

Висновки. В результаті прослуханого майстеркласу можна зробити висновок про високий рівень не лише виконавської майстерності одного 3 найкращих українських музикантів нової генерації Романа Лопатинського: захоплення викликає і його вміння викладати гру на фортепіано, вдумлива манера, вміння слухати учня, виокремлювати головне і досягати результатів навіть у таких короткочасних формах педагогічної діяльності як майстеркласи. Система його педагогічних принципів базується на педантизмі у ставленні до авторських текстів, зверненні особливої уваги на чіткість виконання ритмічних фігур, обов'язковому прояві індивідуальності виконавця, технологічному тяжінні до мінімалізму рухів, визнанні слухового контролю однією із головних якостей музиканта-виконавця. Своїми виконавськими, педагогічними принципами Р.Лопатинський охоче ділиться у численних інтерв'ю, які містяться у мережі інтернет. На нашу думку, вони $є$ корисними і вартими наслідування студентами українських музичних $\mathrm{i}$ музично-педагогічних закладів освіти.

Численні концерти піаніста, багатий репертуарний список, виступи в якості соліста, соліста симфонічного оркестру, концертмейстера, артиста камерних ансамблів дають нам привід для гордості за нашу вітчизняну фортепіанну школу, традиції якої зберігають, продовжують примножують такі талановиті музиканти як Роман Лопатинський.

\section{Jimepamypa:}

1. Лопатинський Р. Хочу стати музикантом https://shamrock.in.ua/2021/03/08/xochustati-muzikantom/

2. Майстерклас Романа Ілліча Лопатинського https://www.youtube.com/watch?v= vBiRg6c8xkc 


\section{References:}

1. Lopatins\&apos;kij, R. Hochu stati muzikantom [I want to become a musician]. (n.d.). shamrock.in.ua. Retrieved from https://shamrock.in.ua/2021/03/08/xochu-stati-muzikantom/ [in Ukrainian].

2. Majsterklas Romana Illicha Lopatins\&apos;kogo [Roman Ilyich Lopatinsky\&apos;s master class].(n.d.). www.youtube.com. Retrieved from https://www.youtube.com/watch?v= vBiRg6c8xkc [in Ukrainian]. 